phire; coloring and painting - agate, onyx, coral; laser drilling - diamond]; the use of artificial products that mimic the appearance of precious, semi-precious, decorative stones, but do not have its chemical composition, physical properties and its structure. Directions of scientific researches on methods of carrying out of gemological researches are envisaged

Keywords: hemological examination, extraction, production, use, operations with precious stones, imitation, reconstructed stones.

УДК 343.98

ORCID iD: https://orcid.org/0000-0002-0515-9761

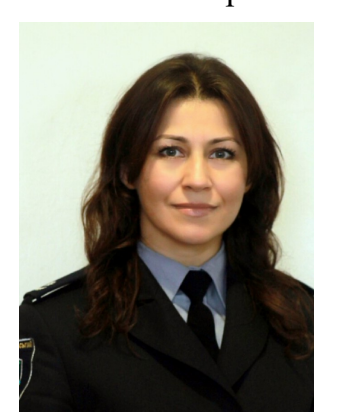

Bidnyak H.S. ${ }^{\circledR}$

$\mathrm{PhD}$

(the Dnipropetrovsk State University

of Internal Affairs)

DOI: 10.31733/2078-3566-2019-1-107-109

\title{
OBTAINING SAMPLES OF PAPILLARY PATERNS: REALITIES AND PROSPECTS
}

Бідняк Г.С. Отримання зразків папілярних візерунків: реалії та перспективи розвитку. Досліджено питання щодо нормативно-правового регулювання дактилоскопіювання живих осіб, проаналізовано думки провідних науковців з цього приводу. Зроблено спробу надати пропозиції щодо законодавчого забезпечення дактилоскопіювання живих осіб з метою забезпечення їх прав та свобод.

Розкрито питання щодо сталих та сучасних способів виявлення та вилучення слідів пальців рук (долоней), а також техніка дактилоскопіювання як живих осіб, так і трупів. Зазначено необхідність дактилоскопіювання осіб не тільки для проведення експертизи, а і задля перевірки осіб за обліками. Проаналізовано сучасний стан нормативно-правового регулювання дактилоскопіювання живих осіб.

Зазначено, що під час наповнення баз даних поліція забезпечує збирання, накопичення мультимедійної інформації та біометричних даних (дактилокартки, зразки ДНК). Відомчі нормативні акти МВС України, норми яких містять пояснення щодо сутності, принципів, завдань дактилоскопічної реєстрації, регламентують діяльність суб'єктів дактилоскопічної реєстрації та визначають об'єкти реєстрації містять значно ширший перелік осіб, що підлягають дактилоскопічній реєстрації, ніж вказані категорії осіб, передбачені Законом України «Про Національну поліцію».

Акцентовано увагу на тому, що законодавчого акту, в якому були б зазначені правова основа дактилоскопічної реєстрації, перелік осіб, які підлягали б обов'язковому та добровільному дактилоскопіюванню із забезпеченням їх прав та свобод, умови та підстави дактилоскопіювання, межі застосування дактилоскопічної інформації, права доступу до неї, умови зберігання та редагування дактилокарт тощо на сьогодні не існує.

Для вирішення зазначеної проблеми запропоновано прийняти окремий закон про дактилоскопіювання живих осіб та трупів, тим самим уникнути виявлені розбіжності.

Ключові слова: дактилоскопіювання, дактилокарта, працівники Наџиональної поліції, підстави дактилоскопіювання.

Formulation of the problem. The conclusions of forensic examinations, verification of a person in a variety of records are of great importance for establishing the circumstances of committing a crime, proving the fault of a person or its absence. Accordingly, each of the parties of the criminal proceedings tries to use the results of expert research in their favor, paying attention not only to the expert's conclusion, but also to compliance with the procedural order for the detection and receipt of objects for examination, in particular, those samples whose affiliation to identifiable object is undoubted.

Accurate and clear regulation of every procedural action allows to use the law properly understand and comply with it. On the contrary, the blurriness, uncertainty of the provisions of

(C) Bidnyak H.S., 2019 
the law creates the possibility of its interpretation of all participants in criminal proceedings for its consideration, taking into account their own interests. This very problem arises during the fingerprinting of living persons.

Analysis of the latest publications that initiated the solution to this problem. Significant contribution to the study of this problem have made: T.V. Averyanova, L.U. Arotsker, V.P. Bakhin, R.S. Belkin, V.D.Bernaz, A.I. Vinberg, A.F. Volobuyev, V.G. Goncharenko, G.I. Gramovich, A.V. Ishchenko, N.I. Klymenko, V.O. Konovalova, U.G. Korukhov, V.S. Kuzmichov, V.K. Lisychenko, V.G. Lukashevich, E..D. Lukianchikov, O.R. Rosinskaya, M.V. Saltevsky, M.Y.. Segay, I.Y. Friedman, V.U. Shepitko, O.R. Shlyakhov, M.G. Shcherbakovsky and others. At the same time, more detailed coverage on the legal basis for fingerprinting of individuals is needed. This is due to changes in procedural legislation and current requirements of practice in the investigation of crimes.

The purpose of this work is to study the problem of obtaining papillary patterns and filling the fingerprint database with qualitative samples.

Basic content. The scientific literature quite fully discloses the question of the sustainable and modern ways of detecting and removing fingerprints (palms), as well as the technique of fingerprinting of both living persons and corpses. Thus, E.A. Razumov emphasizes the traditional procedure for obtaining samples of fingerprints using glass, rubber roller and printing ink, which is used in practical units both earlier and at present [7, p. 26]. Other scientists consider this technique obsolete for various reasons. In order to respect the dignity of the person during fingerprinting, the need to use modern science achievements is indicated. Technologies of "colorless fingerprinting" or scanning, which have been practiced in most foreign countries, allow to receive high-quality prints without the use of paint. If these prints are selected from suspects and accused, they are added to the array of automated databases without further processing and are checked with traces removed from places of undiscovered crimes [2, p.112].

In our opinion, the state of logistics should be taken into account, which is not perfect today. As for this reason, the use of modern devices is not always possible, it is worth paying more attention to the quality of the fingerprint card made (clarity, completeness of the image received, etc.), which can be obtained with sustainable methods. But more problematic is the question of the legality of the selection of such samples, observance of the provisions on the rights and freedoms of citizens specified in the Constitution of Ukraine and other normative legal acts.

As emphasizes O.V. Melnik, reliable protection of human rights - he ultimate test of all state legal institutions, that make up the system of law enforcement and human rights organizations. Including during fingerprinting. The author stresses the danger of collecting and storing data about the private life of people, about their religious and political choices, health, the circle of communication [4, s.201].

As practice shows, the employees of the bodies of pre-trial investigation have questions regarding the grounds for their fingerprinting, including compulsory; the lawfulness of the actions of the subject, who will perform it, and so on.

Article 245 of the Criminal Procedure Code regulates the procedure for obtaining samples for appointment and conducting an examination. In case of necessity of obtaining specimens for examination, they are selected by a party of criminal proceedings, which applied for examination or at the request of which examination was appointed by investigating judge. In the event when the examination is assigned by a court, the selection of samples for its conduct is carried out by a court or on its behalf with the involvement of a specialist.

But fingerprinting of a person is necessary not only for the examination. Almost for every offense there is a need to check the person by records.

Thus art. 26 "On National Police" provides for the formation of information resources by the police. Namely, the police fill in and maintain up to date the records (banks) of the data included in the unified information system of the Ministry of Internal Affairs of Ukraine in relation to persons detained on suspicion of committing offenses (administrative detention, detention according to instructions of law enforcement agencies, detention of individuals by authorities pre-trial investigation, administrative arrest, house arrest).

When filling the databases (banks), the police provide collection, accumulation of multimedia information (photo, video, audio) and biometric data (fingerprints, DNA samples).

However, the departmental regulations of the Ministry of Internal Affairs of Ukraine, the norms of which contain an explanation of the essence, principles, tasks of fingerprint registration, regulate the activities of subjects of fingerprint registration and determine the 
objects of registration contain a much wider list of persons subject to fingerprint registration than the specified categories of persons, stipulated by the Law of Ukraine "On National Police".

In accordance with the Order "On Approval of the Instruction on the Procedure for the Functioning of the Fingerprint Accounting of the Expert Service of the Ministry of Internal Affairs of Ukraine" dated September 11, 2001, No. 785, officers of the Ministry of Internal Affairs carry out fingerprinting of persons who:

- detained on suspicion of committing a crime;

- taken into custody;

- accused of committing a crime;

- subjected to administrative arrest [6].

The Order "On approval of the Instruction on the procedure for the formation, maintenance and use of operational and fingerprint records in the internal affairs bodies and organs (institutions) of the criminal correctional system of Ukraine" of 23.08.2002, No. $823 / 188$, provides a list of objects of operational and fingerprint accounting. These are individuals who are accused of committing crimes or convicts on the territory of Ukraine, are wanted, detained on suspicion of vagrancy, as well as citizens of Ukraine who committed crimes outside their borders and whose information was received by official channels in accordance with international agreements on the exchange of information, which entered into force in due course.

Legislative act, which would specify the legal basis for fingerprint registration, a list of persons who would be subject to mandatory and voluntary fingerprinting with the assurance of their rights and freedoms, the conditions and grounds for fingerprinting, the limits of the use of fingerprint information, access rights to it, the conditions of storage and editing fingerprint card, etc. today unfortunately does not exist.

As a conclusion, one can note the following, for the effective search of persons following the traces of papillary patterns, the following components are necessary: high-quality manufacturing of fingerprint imprints using modern equipment and regular filling of a single fingerprint base. For this we propose to adopt a separate law on fingerprinting of living persons and corpses.

References
1. Про національну поліцію: Закон України від 02.07 .2015 № 580-VIII. URL: http://zakon5.rada.gov.ua/laws/show/580-19

2. Криміналістика: підруч. для студ. вищ. навч. закл. / К.О. Чаплинський, О.В. Лускатов, I.В. Пиріг, В.М. Плетенець, Ю.А. Чаплинська. Дніпропетровськ: Дніпроп. держ. ун-т внутр. справ; Ліра ЛТД, 2014. 380 с.

3. Кримінальний процесуальний кодекс України. Закон України «Про внесення змін до деяких законодавчих актів України у зв'язку з прийняттям Кримінального процесуального кодексу України». Харків: Одіссей, 2012. 360 с.

4. Мельник O.В. Дактилоскопіювання населення сьогодні: варто чи нi? URL: http://irbisnbuv.gov.ua/cgi-

bin/irbis_nbuv/cgiirbis_64.exe?C21COM=2\&I21DBN=UJRN\&P21DBN=UJRN\&IMAGE_FILE_DOW $\mathrm{NLOAD}=1$ \&Image file name=PDF/krise $2013 \quad 58 \% 282 \% 29 \quad 40$. pdf...- C. $200-205$.

5. Про затвердження Інструкції про порядок формування, ведення та використання оперативно-довідкового і дактилоскопічного обліків в органах внутрішніх справ і органах (установах) кримінально-виправної системи України: наказ МВС України від 23.08.2002 № 823/188. URL: http://zakon2.rada.gov.ua/laws/show/z0738-02

6. Про затвердження Інструкції про порядок функціонування дактилоскопічного обліку експертної служби МBC України: наказ МBC України від 11.09.2001 № 785. URL: http://zakon2.rada.gov.ua/laws/show/z1066-01

7. Разумов Э.А. Практическое руководство по криминалистике: учеб.-практ. пособ. / под ред. И.П. Красюка. Москва: ООО «Элит Принт», 2011. 465 с. :илл.

Received to editorial board 04.04.2019

\section{SUMMARY}

The issues of legal regulations of living persons fingerprinting were investigated, opinions of leading scientists on this matter were analyzed. An attempt has been made to provide suggestions for legislative provision of fingerprinting of living persons in order to secure their rights and freedoms.

Keywords: fingerprinting, fingerprint card, national police officers, grounds for fingerprinting 